\section{En bok til alle som ser på diabetikeres føtter}

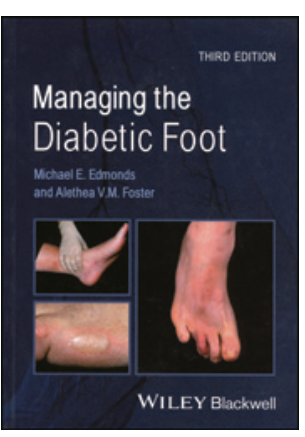

Michael E. Edmonds, Alethea V.M. Foster Managing the diabetic foot

3, utg. 232 s, tab, ill. Chichester: WileyBlackwell, 2014. Pris GBP 40

ISBN 978-0-470-65505-4

Michael Edmonds og Alethea Foster fra Kings's College i London har gjennom de siste 25 årene vært blant de ledende ekspertene på «diabetesfoten». I 2000 publiserte de artikkelen «Simple staging system». Den beskriver på en enkel, men illustrativ og praktisk måte den ofte tragiske utviklingen fra frisk fot hos en diabetiker til amputasjon. Studier viser at opptil $85 \%$ av amputasjonene kunne vært unngått ved bedre profylakse. Mangel på kunnskap om forebygging og behandling av den diabetiske fot er en av grunnene til at altfor mange diabetikere fortsatt må amputere en fot.

De seks hovedkapitlene tar utgangspunktet i fasene $\mathrm{i}$ «the simple staging system». Dette gir boken en logisk og oversiktlig inndeling. Arbeidet mot og med diabetesfotsår er teamwork. Kapitlene i seg selv bygger igjen på seks viktige aspekter teamet må forholde seg til, nemlig å få kontroll på såret, infeksjon, avlastning, sirkulasjon, blod-glukose og opplæring av pasienten. Selv om boken fremstår som kompakt, formidler den all nødvendig kunnskap for å kunne håndtere diabetesføtter, også kunnskap om sjeldne tilstander som Charcot-osteoartropati. Ingen av de aktuelle utrednings- og behandlingsmetodene er utelatt. Sårbehandlingsprinsippene bygger på «wound bed preparation»-prinsippet. Sårbehandlingsprodukter omtales på en nøktern måte, noe som reduserer inntrykket av at det er bandasjen som gjør at sår heler. Det finnes mer enn 150 bilder av god kvalitet.

Kapittel 4, om den infiserte foten, domineres av en flere sider lang tabell om antibiotikabehandling. Her kan man lett få inntrykk av at slik behandling spiller en sentral rolle i hvorvidt man lykkes $\mathrm{i}$ å redde føtter. Selv om det refereres til de siste amerikanske anbefalingene om antibiotikaterapi for diabetiske fotinfeksjoner fra 2012 (1), poengteres ikke nødvendigheten av riktig indikasjon godt nok. Dette kan bidra til et fortsatt overforbruk av antibakterielle midler også hos denne pasientgruppen.

Boken er ment som et kortfattet oppslagsverk for å finne relevant informasjon og å ta raske avgjørelser. Man kunne derfor med fordel ha plassert tabelloversikter på slutten av hvert kapittel for å understreke denne hensikten. Jeg savner også en mer omfattende liste over anbefalt litteratur om emnet.

Denne allikevel meget vellykkede boken anbefales alle som jobber med diabetikere, og som bryr seg om føttene. Den er lettlest og interessant for leger, sykepleiere, fotterapeuter og ortopediingeniører. Lommeformatet gjør at den alltid kan være tilgjengelig. Man får veldig mye nyttig informasjon til en grei pris.

\section{Marcus Gürgen}

Avdelingsoverlege, Kirurgisk-ortopedisk avdeling

Sørlandet sykehus

Flekkefjord

\section{Greit om hjernerystelse, men for hvem?}

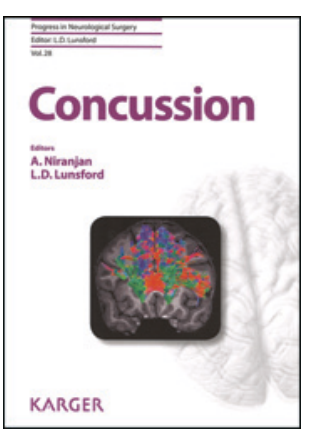

Ajay Niranjan, L. Dade Lunsford, red. Concussion

256 s, tab, ill. Basel: Karger, 2014

Pris CHF 198

ISBN 978-3-318-02648-1

Dette er volum nr. 28 i serien «Progress in Neurological Surgery», en serie publikasjoner som er nesten 50 år - det første volumet kom i 1966.

«Concussion» kan vel best oversettes med «hjernerystelse», og er omtrent like vagt definert. Mange har hatt hjernerystelse, noen av oss flere ganger, og det er derfor en tilstand leger ofte må ta stilling til, i sykehus og legevakter i akuttfasen, for primærleger gjerne i oppfølgingsfasen. Denne boken burde derfor være av interesse for en stor målgruppe, også i Norge, men jeg er likevel ikke så sikker.

Emnevalg og oppbygning er ganske mangelfull. Hvert enkelt kapittel gir for så vidt grei og oppdatert innføring i det valgte emnet, som for eksempel hjernerystelsens biomekanikk, patofysiologi, nevrofysiologi, avanserte radiologiske metoder, kronisk posttraumatisk encefalopati og en rekke andre relevante emner, men jeg savner en helhetlig fremstilling. Ikke $i$ et eneste kapittel finner jeg omtale av hvordan hodeskadepasienter bør håndteres i akuttfasen, eller henvisning til at det faktisk finnes en rekke nasjonale og internasjonale retningslinjer (guidelines) for håndtering av slike pasienter.

På grunn av disse og andre mangler tror jeg de fleste kolleger, som er engasjert $\mathrm{i}$ håndtering $\mathrm{og}$ behandling av slike pasienter, vil finne relativt lite av praktisk interesse i denne utgivelsen. Til det er den informasjonen som fremkommer, ganske skjevfordelt og mer av vitenskapelig karakter enn til praktisk nytte. Følgelig tror jeg at bare et fåtall norske lesere vil ha glede av boken.

Inntil relativt nylig ble hjernerystelse sett på som en uskyldig tilstand som går over av seg selv. Praktisk erfaring, og ikke minst stadig mer avansert radiologisk dokumentasjon, viser at så ikke er tilfellet. Prisverdig vies dette stor plass.

Hele seks av kapitlene er relatert til sport, i første rekke profesjonell («amerikansk») fotball og ishockey, begge idretter hvor hodeskader kan forekomme som en «komplikasjon» til utøvelsen. Litt påfallende er det da at boksing, hvor man faktisk honoreres for å påføre konkurrenten en hjernerystelse (eller verre), ikke vies noen omtale.

I forordet skriver redaktørene: «This volume of ... has assembled a number of international authors ...». For moro skyld telte jeg opp: Hele 49 av i alt 55 forfattere kommer fra USA, og bare to kapitler er skrevet av ikke-amerikanere; resten (17) er skrevet av forfattere fra USA. Det er mulig at disse tallene rettferdiggjør bruken av uttrykket «a number of international authors» - jeg hadde ventet meg et atskillig større internasjonalt bidrag. Det gjelder også referansene til hvert kapittel.

Knut Wester

Professor emeritus, Nevrokirurgisk avdeling

Haukeland universitetssjukehus 